\title{
Fluid flow through the sedimentary cover in northern Switzerland recorded by calcite-celestite veins (Oftringen borehole, Olten)
}

\author{
Antoine de Haller • Alexandre Tarantola • \\ Martin Mazurek · Jorge Spangenberg
}

Received: 14 April 2011/Accepted: 28 September 2011/Published online: 25 November 2011

(C) Swiss Geological Society 2011

\begin{abstract}
Abundant veins filled by calcite, celestite and pyrite were found in the core of a $719 \mathrm{~m}$ deep borehole drilled in Oftringen near Olten, located in the north-western Molasse basin, close to the thrust of the Folded Jura. Host rocks are calcareous marl, argillaceous limestone and limestone of the Dogger and Malm. The $\delta^{18} \mathrm{O}$ values of vein calcite are lower than in host rock carbonate and, together with microthermometric data from fluid inclusions in vein calcite, indicate precipitation from a seawaterdominated fluid at average temperatures of $56-68^{\circ} \mathrm{C}$. Such temperatures were reached at the time of maximum burial of the sedimentary pile in the late Miocene. The depth profile of $\delta^{13} \mathrm{C}$ and ${ }^{87} \mathrm{Sr} /{ }^{86} \mathrm{Sr}$ values and $\mathrm{Sr}$ content of both whole-rock carbonate and vein calcite show marked trends towards negative $\delta^{13} \mathrm{C}$, high ${ }^{87} \mathrm{Sr} /{ }^{86} \mathrm{Sr}$, and low $\mathrm{Sr}$ content in the uppermost $50-150 \mathrm{~m}$ of the Jurassic profile (upper Oxfordian). The ${ }^{87} \mathrm{Sr} /{ }^{86} \mathrm{Sr}$ of vein minerals is generally higher than that of host rock carbonate, up to very high values corresponding to Burdigalian seawater (Upper Marine Molasse, Miocene), which represents the last marine incursion in the region. No evidence for internally
\end{abstract}

Editorial handling: Edwin Gnos.

A. de Haller $(\bowtie) \cdot$ A. Tarantola $\cdot$ M. Mazurek

Rock-Water Interaction, Institute of Geological Sciences,

University of Bern, Baltzerstrasse 1-3, 3012 Bern, Switzerland

e-mail: Dehaller@geo.unibe.ch

Present Address:

A. Tarantola

Faculté des Sciences, Université Henri Poincaré,

BP239, 54506 Vandoeuvre-lès-Nancy, France

J. Spangenberg

Institute of Mineralogy and Geochemistry, University

of Lausanne, Building Anthropole, 1015 Lausanne, Switzerland derived radiogenic $\mathrm{Sr}$ (clay minerals) has been found and so an external source is required. S and $\mathrm{O}$ isotope composition of vein celestite and pyrite can be explained by bacterial reduction of Miocene seawater sulphate. The available data set suggests the vein mineralization precipitated from descending Burdigalian seawater and not from a fluid originating in the underlying Triassic evaporites.

Keywords Isotope - Fluid inclusions - Mesozoic · Miocene $\cdot$ Burdigalian

\section{Introduction}

Veins filled by calcite, celestite and subordinate pyrite have been documented in the Mesozoic sedimentary cover of the Swiss plateau and the Jura (Weibel 1966; Meisser 1997; Stalder et al. 1998; Waber and Schürch 2000; Pearson et al. 2003), but to date, their origin has not been thoroughly explored. The present work studies vein materials that were identified in cores from the geothermal borehole drilled in 2007 near Oftringen (Canton of Aargau, Switzerland). The main objective of the study was to constrain the timing, temperature and origin of the fluids involved in the precipitation of the vein minerals, as well as the geodynamic context. This was achieved by petrographic/mineralogical studies, fluid-inclusions microthermometry and analyses of the isotopic composition $(\mathrm{C}, \mathrm{O}, \mathrm{S}, \mathrm{Sr})$ of vein minerals and surrounding host rocks.

\section{Methodology}

Carbon and oxygen isotope ratios of whole rock carbonate were measured on $1 \mathrm{~g}$ powder aliquots of the same samples 
that were analysed for Sr. Vein calcite was micro-drilled with a $2 \mathrm{~mm}$ diamond drill. The stable $\mathrm{C}$ and $\mathrm{O}$ isotope composition was measured at the University of Bern on a Finnigan Delta V Advantage mass spectrometer equipped with an automated carbonate preparation system (Gas Bench-II). The $\delta^{13} \mathrm{C}$ results are reported relative to the Vienna-Pee Dee Belemnite (V-PDB) standard, whilst $\delta^{18} \mathrm{O}$ values refer to the Vienna Standard Mean Ocean Water (V-SMOW) standards; standardization was accomplished using international standards NBS 19 and NBS 18 (Friedman et al. 1982).

Sampling of vein celestite for sulphur and oxygen isotope measurements was done with a diamond micro-drill. Samples were dissolved in $\mathrm{HCl}$ and, after removal of $1 \mathrm{ml}$ of the acid solution for $\mathrm{Sr}$ isotope analysis, the dissolved sulphate was precipitated as $\mathrm{BaSO}_{4}$ by addition of $\mathrm{BaCl}_{2} \cdot 2 \mathrm{H}_{2} \mathrm{O}$. The precipitate was then washed with water and ethanol and dried. Pyrite samples were also microdrilled and did not require specific preparation. Sulphur isotope ratios of pyrite and celestite and oxygen isotope ratios of celestite were measured at the University of Lausanne (Switzerland) using the method described in Dold and Spangenberg (2005), and Giesemann et al. (1994). The stable isotope compositions of sulphur and oxygen are reported in delta $(\delta)$ notation relative to the Vienna Canyon Diablo Troilite (V-CDT) and to the V-SMOW standards, respectively.

The strontium isotopic composition of whole rock carbonate, vein celestite $(1 \mathrm{ml}$ aliquots of the $\mathrm{HCl}$ solutions prepared for $\mathrm{S}-\mathrm{O}$ isotope measurements) and vein calcite (obtained by diamond micro-drilling) was analysed at the University of Bern (Switzerland). The Sr from the whole rock carbonate fraction was recovered from about $100 \mathrm{mg}$ of rock powder that were leached with $10 \%$ acetic acid, centrifuged, and dried. The carbonate content was estimated from the weight loss after the acid leach. Vein calcite samples (4-12 mg) and leachates of whole rock and celestite were spiked with an ${ }^{84} \mathrm{Sr}$ solution. Sr separation was carried out in miniature $(0.6 \mathrm{ml}$ resin bed) ion exchange columns using EiChrom Sr Spec ${ }^{\circledR}$ resin. Prior to mass spectrometry, the sample was treated in oxygen plasma at 0.1 mbar to remove organic residues from the resin. $\mathrm{Sr}$ isotope ratios were measured in a $\mathrm{Nu}$ Instruments ${ }^{\mathrm{TM}}$ multicollector ICP mass spectrometer, and an ESI Apex-Q ${ }^{\circledR}$ desolvating inlet systems with an ESI microflow $^{\circledR}$ nebulizer. A fractionation correction was made via ${ }^{88} \mathrm{Sr} /{ }^{86} \mathrm{Sr}$ using the exponential law, and a correction for mass interferences with very minor $\mathrm{Kr}$ and $\mathrm{Rb}$ in the samples was also applied. Sample measurements were done in static mode, comprising between 30 and 45 individual ratio measurements. The NIST SRM 987 standard (Moore et al. 1982) was measured recurrently, usually every five samples.
Microthermometric measurements were performed on vein calcite and celestite using a Linkam heating-cooling stage calibrated using the $\mathrm{CO}_{2}$ triple point at $-56.6 \pm$ $0.1^{\circ} \mathrm{C}$, the $\mathrm{H}_{2} \mathrm{O}$ triple point at $0.0^{\circ} \mathrm{C}$ and the $\mathrm{H}_{2} \mathrm{O}$ critical point at $374.1 \pm 1.0^{\circ} \mathrm{C}$. Accuracy of measurements is in the range $\pm 0.1{ }^{\circ} \mathrm{C}$ below $30^{\circ} \mathrm{C}$ and $\pm 1{ }^{\circ} \mathrm{C}$ at higher temperatures. Temperatures of ice melting $T_{m}$ (ice) and of homogenization in the liquid phase $T_{h}(1+\mathrm{v} \rightarrow 1)$ were measured. In the studied samples, the gas bubble observed in some of the inclusions at room temperature disappeared by ice expansion on freezing, leading to super-heated ice melting with $T_{m}$ (ice) ranging between -0.4 and $+4^{\circ} \mathrm{C}$. To avoid super-heating, a large enough gas bubble was obtained by stretching the fluid inclusion through multiple cycles of freezing to around -40 to $-50^{\circ} \mathrm{C}$ (e.g., Roedder 1984). For both liquid and liquid-vapour inclusions, $T_{m}$ (ice) was obtained by systematically applying this stretching procedure. The fluid salinity was derived from the ice melting temperature according to Bodnar (1993). The obtained $\mathrm{NaCl}$ equivalent salinity is an approximation that does not consider the potential presence of other salts (e.g., $\mathrm{CaCl}_{2}, \mathrm{MgCl}_{2}$ ). Raman spectra of host minerals, gas bubbles and trapped solids were obtained with a green laser light at $532.12 \mathrm{~nm}$ with $20 \mathrm{~s}$ accumulation time on a JobinYvon spectrometer.

\section{Geological setting}

The studied area was covered by sea from the Upper Triassic (225 Ma) to the end of the Cretaceous (65 Ma; Mazurek et al. 2006, and references therein). Since then, continental conditions with erosion or Freshwater Molasse sedimentation prevailed until present except during the Burdigalian (21-17 Ma, Miocene) when marine conditions are recorded by the Upper Marine Molasse, which has been eroded at the drill site (Kuhlemann and Kempf 2002). Two burial stages are recognized in northern Switzerland, during the Cretaceous and the Miocene, separated by an early Tertiary uplift event (Mazurek et al. 2006). The Jura belt formed between 10.5 and $3 \mathrm{Ma}$, when the Mesozoic-Tertiary sequence has been folded towards the North-East, the detachment horizon being located in Triassic evaporites (Berger 1996; Becker 2000).

The $719 \mathrm{~m}$ deep Oftringen borehole is located in the Subjurassic zone of the Molasse basin, about $2 \mathrm{~km}$ south of the Born-Engelberg anticline and $4 \mathrm{~km}$ away from the back front of the Folded Jura (Fig. 1). The drilled profile (Fig. 2) includes the Lower Freshwater Molasse (Oligocene-Miocene), underlain by a thin Eocene shale layer (Boluston). An unconformity separates the PaleogeneNeogene deposits from the underlying Malm (Letzi, Wangen, Crenularis, and Geissberg Members and Wildegg 


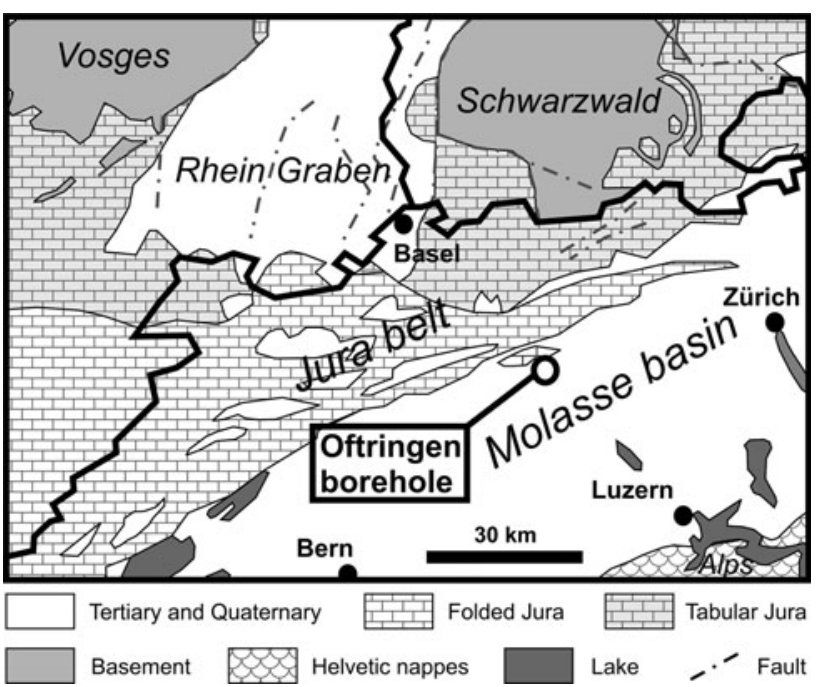

Fig. 1 Location map and tectonic units

Formation, including Effingen and Birmenstorf Members) and late Dogger units (Hauptrogenstein Formation). The whole Mesozoic succession and a part of the Tertiary have been cored.

\section{Vein petrography}

Veins (max. $5 \mathrm{~cm}$ thick) were found in all types of lithologies throughout the Jurassic profile (Hauptrogenstein Formation up to the Geissberg Member), with frequencies of up to 8 veins per $\mathrm{m}$ along hole (Fig. 3). In contrast, no veins were recognized in the overlying Molasse. Illustrations of the vein materials are shown in Fig. 4.

Most of the structures are related to tectonic activity, with the exception of karst collapse breccias recognized in the upper Geissberg Member limestone. Veins are completely sealed by minerals, with the exception of some strike-slip veins (Fig. 4a-c). Veins are generally better developed in limestones than in clay-rich rocks (Fig. 4b). Three types of filling material are found: (1) clay, (2) calcite, (3) calcite and celestite. Clay is exclusively found filling karst cavities in the Geissberg Member. Calcite is found in all types of structures from the Geissberg Member down to the Hauptrogenstein Formation. Calcite can be macro-crystalline ( $>1 \mathrm{~mm}$ crystals) or microcrystalline $(<0.2 \mathrm{~mm})$, the latter showing geopetal sedimentary textures suggesting deposition as mud within the open space structures. Macrocrystalline calcite is locally accompanied by brownish, isotropic and poorly reflecting organic matter (Fig. 4d). The association calcite-celestite occurs in veins in the Effingen Member, between 568 and $607 \mathrm{~m}$ depth (Fig. 4e). Celestite is generally precipitated early and idiomorphic $(<1 \mathrm{~cm}$ crystals), overgrown or locally replaced

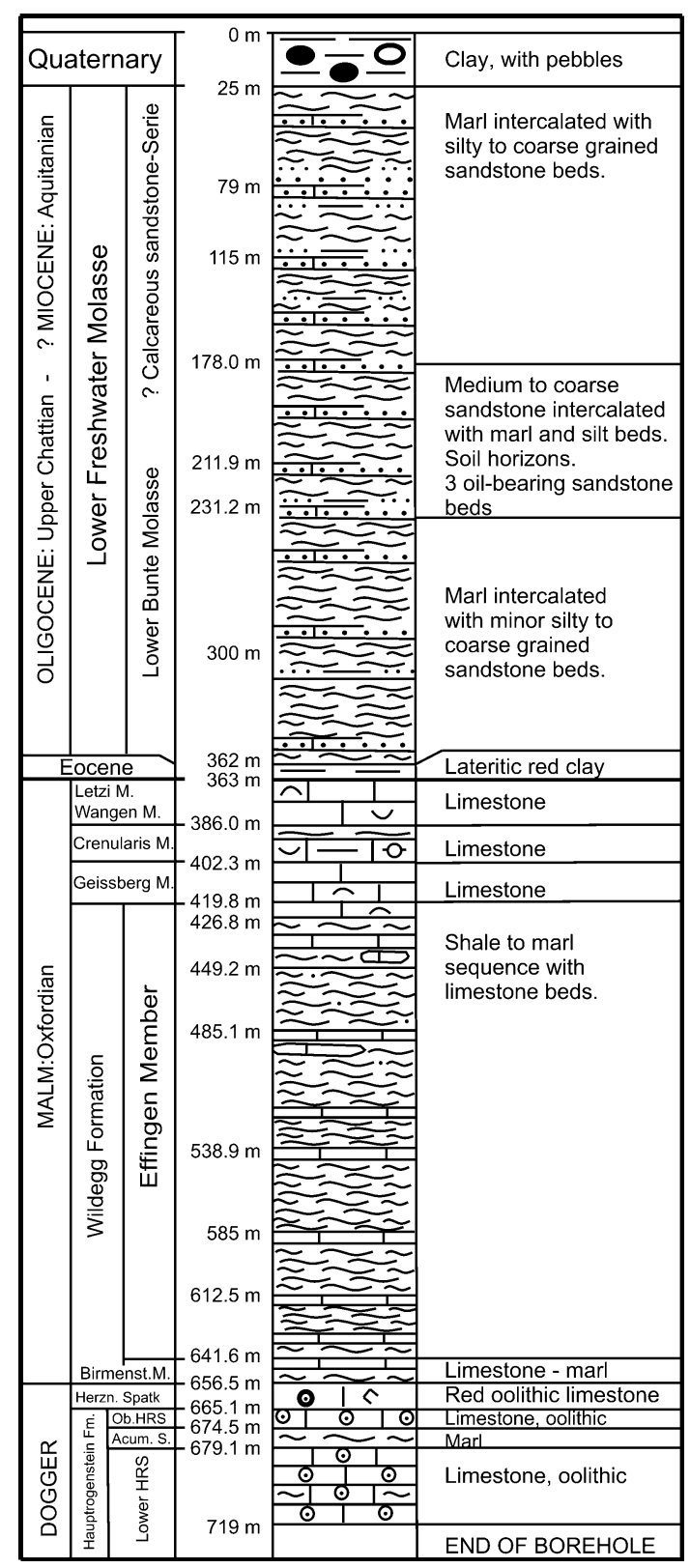

Fig. 2 Geological profile of the Oftringen borehole (simplified after Albert and Bläsi 2008)

by later macrocrystalline calcite (Fig. 4e). Pyrite can be found in minor amounts (Fig. 4e). When identifiable, the tectonic regimes associated with the sampled veins are varied and include extensional, compressional and strikeslip structures. Karst structures were generated during the subaerial exposure of the sedimentary pile which took place during the Palaeogene. However, although karstification and clay-rich fillings are probably coeval, calcite filling these structures could be younger (precipitated from fluids circulating in tectonically reactivated karst structures). The age of the fault-related veins cannot be 


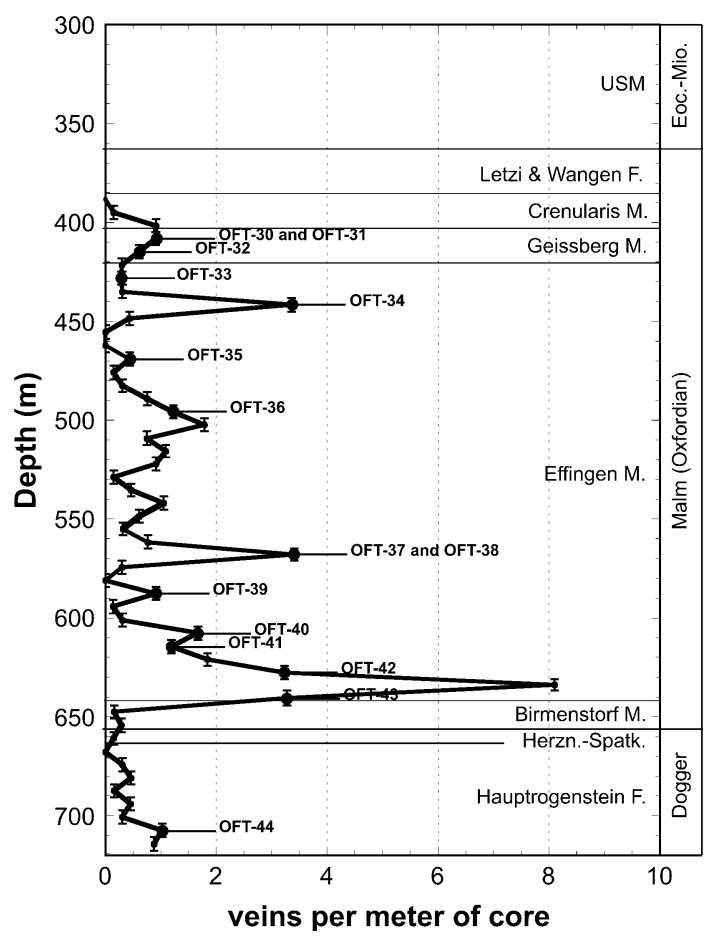

Fig. 3 Vein frequency along the cored lower part of the Oftringen borehole. The indicated values are averages along 6-7 $\mathrm{m}$ long core segments (shown by vertical bars)

constrained by petrographic arguments, and cross-cutting relationships were not observed.

\section{Results}

\subsection{Fluid inclusions in vein calcite and celestite}

Petrography, microthermometric and Raman-microprobe results of fluid-inclusion studies are presented in Table 1 and shown graphically in Figs. 5 and 6. The full dataset of fluid inclusions measurements can be found in Waber (2008). Three types of fluid inclusions were observed in decreasing abundance: (1) single phase liquid; (2) two phases liquid-vapour; (3) single phase gas. The first two types are intimately associated in similar textural settings in both calcite and celestite. Trails of elongated gas-only fluid inclusions were locally found in calcite. Fluid inclusions in celestite are aligned along fractures that never cut calcite grains, suggesting that these fluid inclusions predate the precipitation of calcite. All fluid inclusions in calcite are located along cleavage planes. The shape of these inclusions ranges from angular, negative crystal-like to irregular. It was not possible, according to geometric criteria, to determine whether the fluids were trapped during calcite growth or whether they correspond to a later brittle event. In calcite, accidentally trapped solids consist of dark reddish grains and transparent rhombohedra. The first could not be determined but the Raman spectrum of the latter corresponds to dolomite. Small transparent accidentally trapped solids were observed in about one third of the small single-phase liquid inclusions in celestite. Their Raman spectrum corresponds to apatite. The Raman spectra of one-phase liquid inclusions in celestite and calcite correspond to water, and no $\mathrm{CO}_{2}$ or $\mathrm{CH}_{4}$ were detected. Raman analyses of the vapour bubbles in calcite and celestite showed the presence of methane, evidenced by a vibrational band at $2,917 \mathrm{~cm}^{-1}$. All samples were placed under UV-light, and no traces of fluorescent hydrocarbons were detected in the inclusions.

$T_{m}$ (ice) in celestite ranges between -1.4 and $-3.2^{\circ} \mathrm{C}$, corresponding to salinities of $2.4-5.3$ wt.\% eq. $\mathrm{NaCl}$ (Table 1; Fig. 5). The range for $T_{\mathrm{m}}$ (ice) in calcite is -1.2 to $-2.9^{\circ} \mathrm{C}$, corresponding to salinities of $1.4-4.8 \mathrm{wt} . \%$ eq. $\mathrm{NaCl}$. The wide salinity ranges indicate that fluids were trapped over a time period in which their chemical composition varied. However, there is no textural evidence that would constrain their relative ages, so the exact evolution cannot be reconstructed. The average salinities in celestite fluid inclusions (3.3-4.4 wt.\% eq. $\mathrm{NaCl}$ ) are slightly higher than those in calcite $(2.6-2.7$ wt.\% eq. $\mathrm{NaCl})$. When measured, fluid inclusions showed an eutectic temperature at around $-20.8^{\circ} \mathrm{C}$, indicating the presence of dissolved $\mathrm{NaCl}$.

Homogenization occurs into the liquid phase, and average homogenization temperatures of calcite-hosted fluid inclusions fluctuate between 56 and $68^{\circ} \mathrm{C}$, with individual values ranging from 47 to $83^{\circ} \mathrm{C}$ (Table 1; Fig. 6). No reliable homogenization temperatures were obtained from celestite-hosted fluid inclusions due to stretching and leaking during heating. Considering that the P-T conditions of the involved fluids must be in the range of the burial conditions (Mazurek et al. 2006), the sampled veins formed at moderate depths and temperatures where the homogenization temperatures of fluid inclusions nearly correspond to the true trapping temperature and thus require no pressure correction (e.g., Roedder 1984). There is no correlation between homogenization temperature and salinity.

At the low homogenization temperatures obtained from calcite, the gas bubble may fail to nucleate at room temperature due to metastable behaviour. It follows that liquid and liquid-vapour fluid inclusions in calcite and celestite probably belong to the same population. This is corroborated by the observation that salinities of these two types of inclusions in celestite are similar (Table 1) and by the fact that they occur in close association. Finally, fluid inclusions in all samples show similar ranges of homogenization temperatures and salinities, compatible with all vein minerals having formed from a single hydrothermal event. 
Fig. 4 Illustrations of vein infills on meso- and microscopic scale (core diameter is $10 \mathrm{~cm}$ ). a Sample 415.72, Geissberg Member limestone cut by a calcite vein showing subhorizontal striation. b Sample 443.78, bedded Effingen Member limestone and calcareous marl cut by calcite veins. Veins are better developed in the limestone bed. c Sample 569.33, bedded Effingen Member sandy calcareous marl cut by a calcitecelestite vein. d Sample 409.42, Geissberg Member limestone cut by a calcite vein containing brown organic matter. e Sample 586.73, Effingen Member. Celestite-calcite-pyrite vein. Celestite crystals are idiomorphic and were overgrown by later calcite. f Sample 708.18,

Hauptrogenstein Formation. Calcite vein crosscutting oolitic limestone. Stylolithic joints are present along the edge of the vein and indicate that highest pressures were reached after vein calcite precipitation. $\mathbf{d}$ and $\mathbf{f}$ are in parallel polarized transmitted light, whereas e is in crossed polarized transmitted light
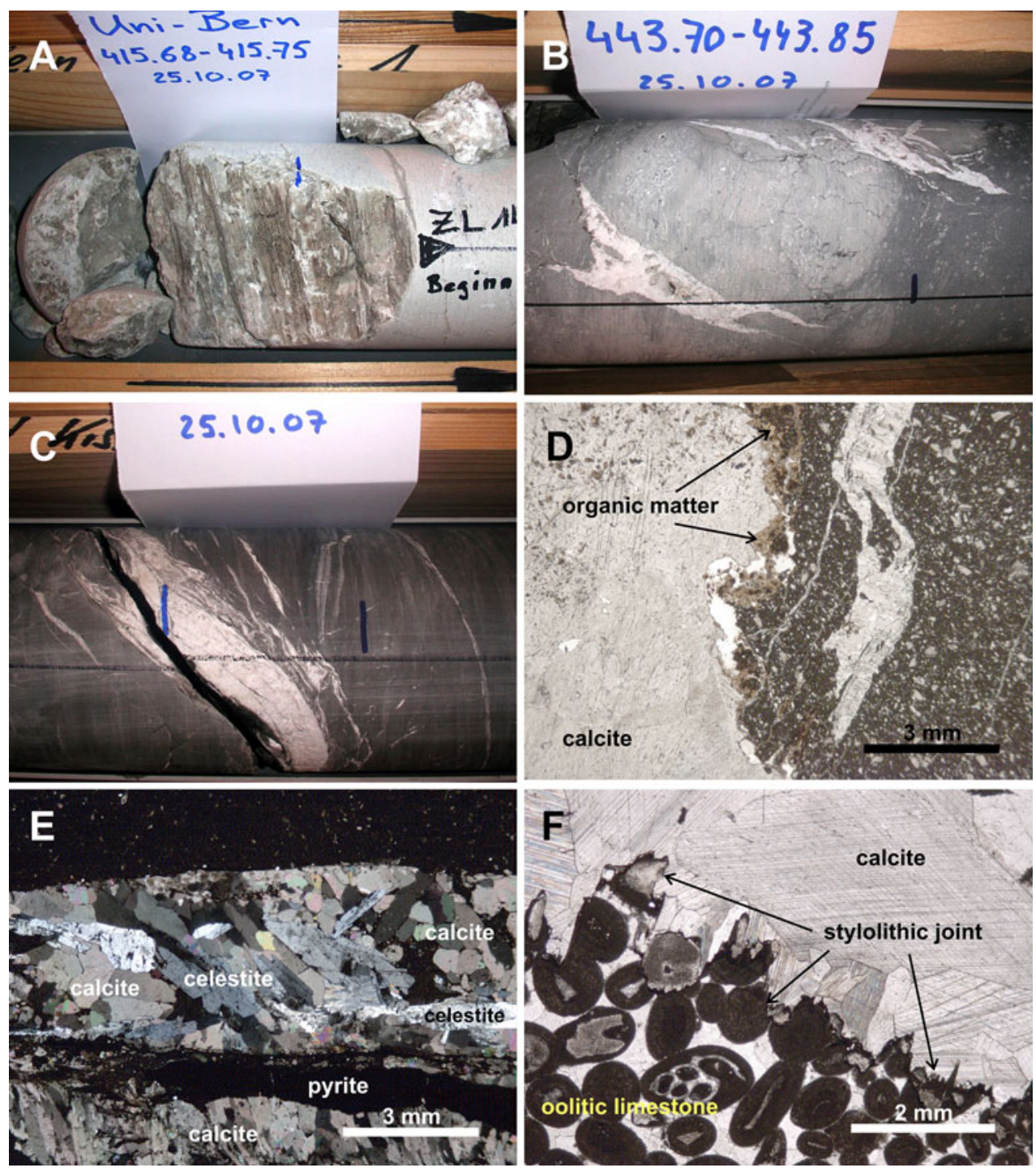

5.2 Isotope composition of the host rock carbonate and of the vein minerals

Isotopic compositions of $\mathrm{C}, \mathrm{O}, \mathrm{S}$ and $\mathrm{Sr}$ are given in Tables 2 (whole rock carbonate) and 3 (vein minerals).

\subsubsection{Carbon and oxygen isotopes of carbonates}

Results relating to whole rock carbonate indicate welldefined depth profiles (Table 2; Fig. 7). The $\delta^{13} \mathrm{C}$ profile is curved, with values ranging from -2.0 to $1.1 \%$ V-PDB in the Crenularis and Geissberg Members and increasing with depth to values between 2.0 and $2.9 \%$ V-PDB in the deeper units. These values are both lower and higher than that for Oxfordian seawater carbonate (broadly at 1\% PDB, Holser et al. 1995; Ripperdan 2001), and partly fit with the range of published whole rock carbonate $\delta^{13} \mathrm{C}$ for Oxfordian rocks from the northern Tethys, from around
1.3-3.4 \%o PDB (Weissert and Erba 2004). Whole rock carbonate $\delta^{18} \mathrm{O}$ values fluctuate within a narrow range (25.2-28.3\% V-SMOW) over the whole profile.

The $\delta^{13} \mathrm{C}$ values of vein calcite range from -1.4 to $+3.1 \%$ V-PDB (Table 3; Fig. 7). Three samples show values undistinguishable from the host rock carbonate, but other samples show slightly diverging values. The $\delta^{18} \mathrm{O}$ of vein calcite ranges from 17.5 to $24.3 \%$ V-SMOW and is systematically lower than the corresponding whole rock carbonate value (Fig. 7). The difference varies between about 2 and $8 \%$.

\subsubsection{Sulphur and oxygen isotopes of celestite and sulphur isotopes of pyrite}

The $\delta^{34} \mathrm{~S}$ value of vein celestite ranges from 22.5 to $26 \%$ V-CDT, while the $\delta^{18} \mathrm{O}$ values fluctuate between 13.2 and $17.6 \%$ V-SMOW (Table 3; Fig. 8). The pairs of 


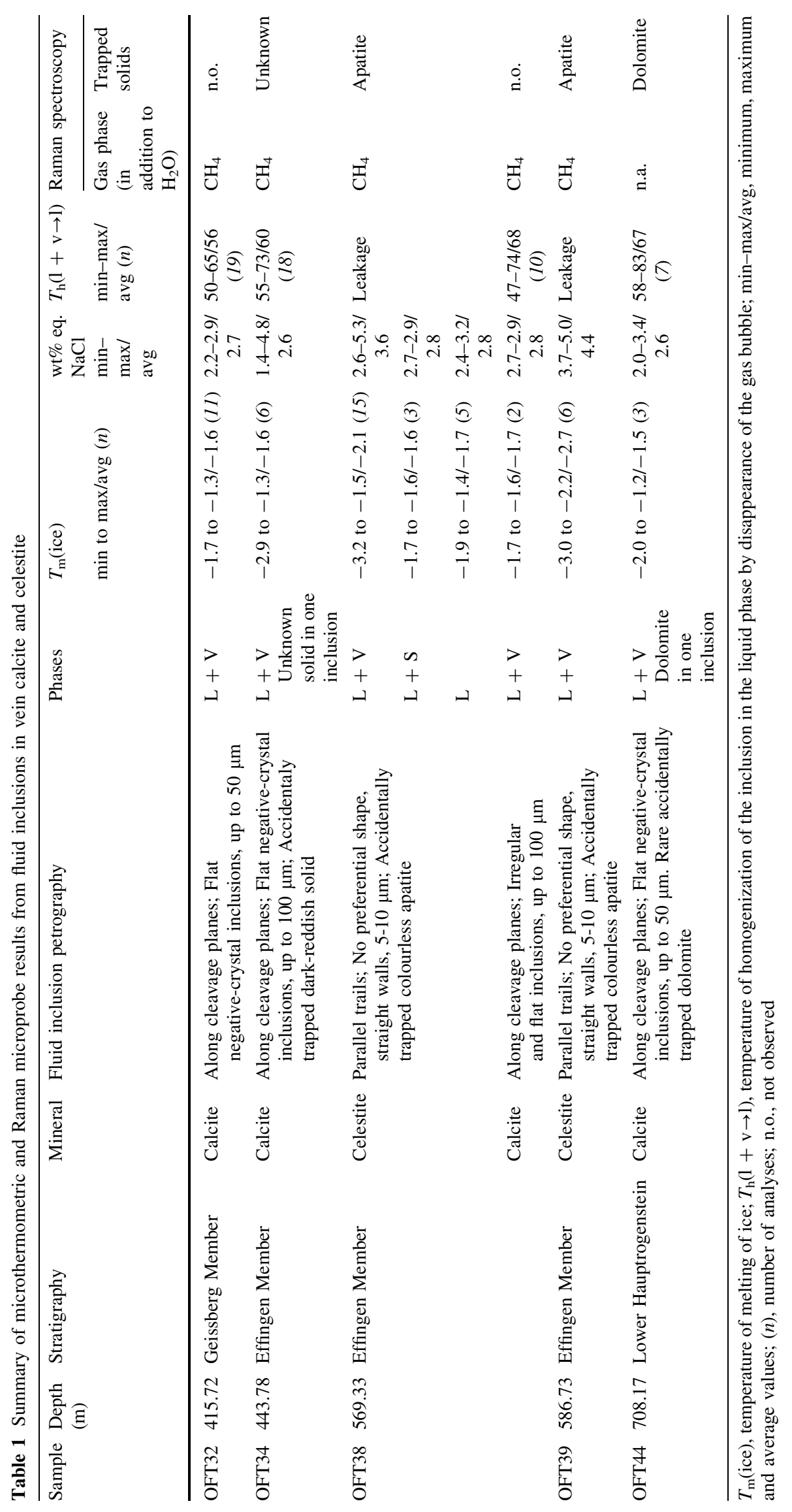




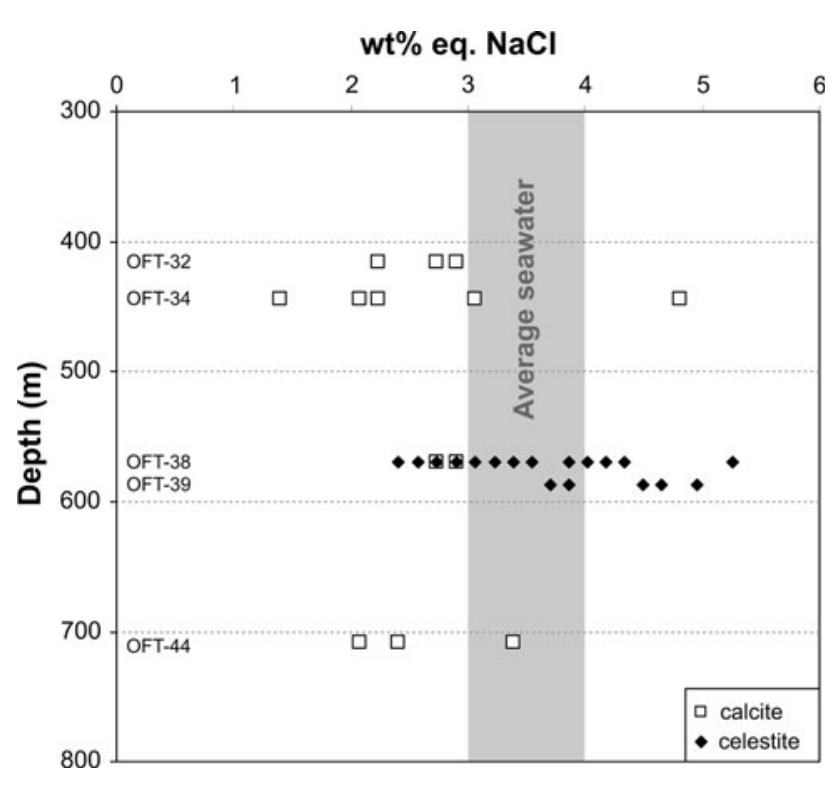

Fig. 5 Salinity of fluid inclusions in vein calcite and celestite

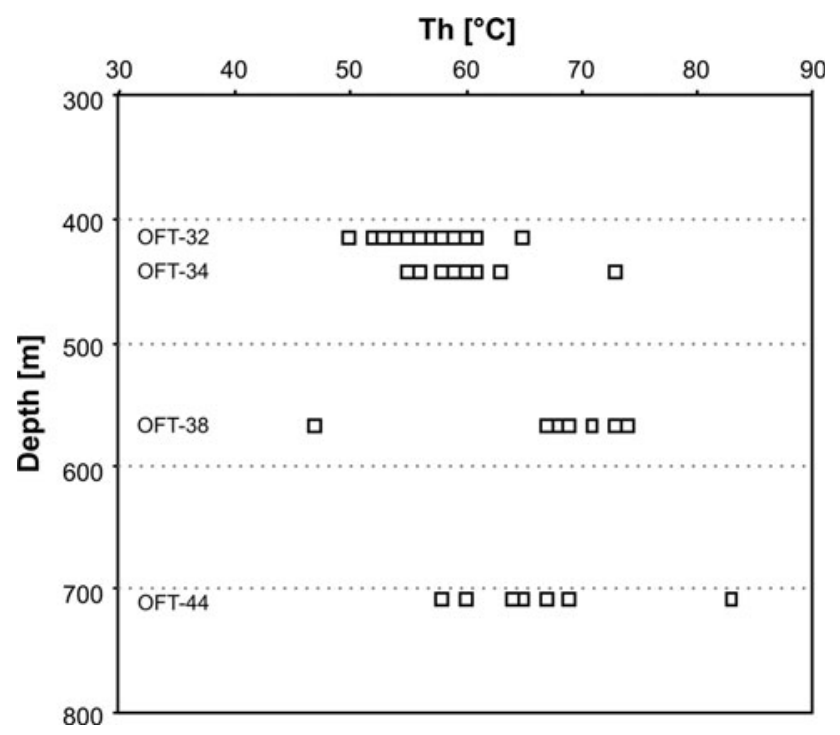

Fig. 6 Homogenization temperatures of fluid inclusions in vein calcite

measurements performed on different subsamples from the same vein show some differences in $\delta^{18} \mathrm{O}$, but these are not systematic.

The $\delta^{34} \mathrm{~S}$ values for celestite are all above the maximum average value for seawater sulphate during Mesozoic and Cenozoic times, at $22 \%$ V-CDT (Claypool et al. 1980), and in part above the range of published data for Miocene evaporites of northern Switzerland and Germany (Fig. 8; Balderer et al. 1991). The $\delta^{18} \mathrm{O}$ values fall into the Triassic seawater range but are partly above Jurassic and Miocene values (Fig. 8). The isotopic composition of Upper Buntsandstein sulphate (Balderer et al. 1991) would fit with the obtained $\delta^{34} \mathrm{~S}$ values but not with the $\delta^{18} \mathrm{O}$. Analysed vein pyrite has strongly negative $\delta^{34} \mathrm{~S} \quad(<-30 \%$ V-CDT $)$, compatible with bacterial sulphate reduction.

\subsubsection{Strontium isotopes of carbonate and sulphate minerals}

The ${ }^{87} \mathrm{Sr} /{ }^{86} \mathrm{Sr}$ ratios of whole rock carbonate follow a welldefined depth profile with minimum values around 0.707 in the middle part of the Effingen Member (Table 2; Fig. 9). The ratio increases downward in the sequence and, much more strongly, upward. In the Effingen Member, samples with the lowest ${ }^{87} \mathrm{Sr} /{ }^{86} \mathrm{Sr}$ ratio are close to the Oxfordian seawater value (Fig. 9; McArthur et al. 2001). Similarly, the ${ }^{87} \mathrm{Sr} /{ }^{86} \mathrm{Sr}$ ratio of the Hauptrogenstein limestone falls within the range of Dogger seawater. All other samples are enriched in radiogenic $\mathrm{Sr}$ compared to contemporary seawater. No correlation is observed between ${ }^{87} \mathrm{Sr} /{ }^{86} \mathrm{Sr}$ and the total clay content or that of any individual clay mineral (Waber 2008). This suggests that the siliciclastic portion has not been affected by significant recrystallizationalteration processes (able to release radiogenic $\mathrm{Sr}$ into the pore water) since the time of deposition, and that no significant amounts of $\mathrm{Sr}$ were released from silicates during the acetic acid leach. Vein minerals tend to have higher ${ }^{87} \mathrm{Sr} /{ }^{86} \mathrm{Sr}$ compared to the whole rock carbonate fraction at similar depth (Fig. 9), and the highest values reached at the top of the profile are similar to that of Burdigalian seawater (Fig. 10), which was present in the studied area during the deposition of the Upper Marine Molasse. Figure 10 shows that the ${ }^{87} \mathrm{Sr} /{ }^{86} \mathrm{Sr}$ ratio of whole rock carbonate and vein minerals follow a broad trend where higher ${ }^{87} \mathrm{Sr} /{ }^{86} \mathrm{Sr}$ corresponds to lower $\mathrm{Sr}$ content, which could indicate a mixing between two sources. Similarly, low $\delta^{13} \mathrm{C}$ correlates with low Sr content and high ${ }^{87} \mathrm{Sr} /{ }^{86} \mathrm{Sr}$ ratio (Figs. 11, 12). The trends for vein carbonate suggest mixing between two reservoirs, one with low ${ }^{86} \mathrm{Sr} /{ }^{87} \mathrm{Sr}$, high $\mathrm{Sr}$ content and positive $\delta^{13} \mathrm{C}$ and the other with high ${ }^{86} \mathrm{Sr} /{ }^{87} \mathrm{Sr}$, low $\mathrm{Sr}$ content and negative $\delta^{13} \mathrm{C}$. The data for whole rock carbonate suggest a similar mixing, although some more complex processes (unsolved) might explain the dispersion for data with negative $\delta^{13} \mathrm{C}$ values.

\section{Discussion}

The range of $\delta^{18} \mathrm{O}$ values in whole rock carbonate (Fig. 7) is largely consistent with precipitation at isotopic equilibrium with seawater in a tropical climate (Fig. 13) and compares well with published data on Malm carbonate rocks of the Helvetic Nappes of eastern Switzerland (Marquer and Burkhard 1992). However, the slight deviations toward lower values observed in samples at the top and bottom of the profile suggest that the oxygen isotopic 
Table 2 Strontium, carbon and oxygen isotope composition of whole-rock carbonate

\begin{tabular}{|c|c|c|c|c|c|c|c|c|c|c|}
\hline Sample & Depth (m) & Formation & Lithology $^{\mathrm{a}}$ & $\mathrm{Sr}(\mathrm{ppm})$ & ${ }^{87} \mathrm{Sr} /{ }^{86} \mathrm{Sr}$ & $\begin{array}{l}\text { Error } \\
2 \sigma \text { (abs.) }\end{array}$ & $\begin{array}{l}\delta^{13} \mathrm{C} \\
\% \text { V-PDB }\end{array}$ & $\begin{array}{l}\text { Error } \\
1 \sigma \text { (abs.) }\end{array}$ & $\begin{array}{l}\delta^{18} \mathrm{O} \\
\% \text { V-SMOW }\end{array}$ & $\begin{array}{l}\text { Error } \\
1 \sigma \text { (abs.) }\end{array}$ \\
\hline OFT-7 & 393.13 & Crenularis Member & Limestone & 206 & 0.707888 & 0.000020 & -0.49 & 0.05 & 25.33 & 0.05 \\
\hline OFT-8 & 399.59 & Crenularis Member & Argillaceous limestone & 194 & 0.708103 & 0.000032 & 1.11 & 0.04 & 26.86 & 0.02 \\
\hline OFT-30 & 409.42 & Geissberg Member & Limestone & 147 & 0.707719 & 0.000029 & -1.99 & 0.06 & 25.66 & 0.06 \\
\hline OFT-10 & 425.06 & Effingen Member & Limestone & 220 & 0.707307 & 0.000020 & 1.95 & 0.06 & 26.60 & 0.06 \\
\hline OFT-11 & 438.88 & Effingen Member & Argillaceous limestone & 534 & 0.707116 & 0.000020 & 1.99 & 0.06 & 26.75 & 0.06 \\
\hline OFT-15 & 462.59 & Effingen Member & Sandy calcareous marl & 744 & 0.707188 & 0.000020 & 2.14 & 0.06 & 26.71 & 0.06 \\
\hline OFT-19 & 492.65 & Effingen Member & Argillaceous limestone & 767 & 0.707049 & 0.000020 & 2.56 & 0.06 & 26.64 & 0.06 \\
\hline OFT-22 & 544.53 & Effingen Member & Argillaceous limestone & 742 & 0.706923 & 0.000020 & 2.81 & 0.06 & 27.16 & 0.06 \\
\hline OFT-24 & 571.37 & Effingen Member & Calcareous marl & 892 & 0.707033 & 0.000020 & 2.89 & 0.06 & 27.38 & 0.06 \\
\hline OFT-26 & 619.07 & Effingen Member & Sandy calcareous marl & 1,035 & 0.707140 & 0.000020 & 2.72 & 0.06 & 25.93 & 0.06 \\
\hline OFT-29 & 648.11 & Birmenst. Member & Sandy calcareous marl & 601 & 0.707141 & 0.000020 & 2.62 & 0.06 & 28.29 & 0.06 \\
\hline OFT-44 & 708.18 & Lower Hauptrogenstein & Oolitic limestone & 383 & 0.707255 & 0.000020 & 2.14 & 0.06 & 25.23 & 0.06 \\
\hline
\end{tabular}

${ }^{a}$ Using the classification scheme of Füchtbauer (1988), based on the relative contents of quartz + feldspar, carbonates, and clay minerals

values may have been weakly perturbed by later events (carbonate recrystallization, replacement, cementation).

The $\delta^{18} \mathrm{O}$ values of calcite veins are consistently below those of the whole rocks. Microthermometric data indicate that vein calcite precipitated at average temperatures of $56-68^{\circ} \mathrm{C}$ from moderately saline fluids. At such conditions, a fluid in isotopic equilibrium with the $\delta^{18} \mathrm{O}$ values of vein calcite would have had a $\delta^{18} \mathrm{O}_{\mathrm{H}_{2} \mathrm{O}}$ close to zero, consistent with a predominantly marine origin (Fig. 13). The range of salinities obtained from fluid-inclusion data (1.4-5.3 wt\% $\mathrm{NaCl}$ eq.) indicates that fluid chemistry varied over time, for example due to mixing processes.

In Fig. 7, it is seen that $\delta^{13} \mathrm{C}$ values of matrix carbonate are higher than those of seawater carbonate at the time of deposition in the Effingen Member down to the Hauptrogenstein Formation. This might indicate that the sediments originally contained major amounts of primary aragonite, which is enriched in ${ }^{13} \mathrm{C}$ compared to calcite (Romanek et al. 1992). In contrast, the pronounced negative excursion in the Crenularis and Geissberg Members suggests diagenetic cementation or replacement by carbonates containing isotopically light carbon produced through oxidation of organic matter. The $\delta^{13} \mathrm{C}$ values of vein calcites are generally in disequilibrium with their host rocks.

Dissolved sulphate that was incorporated into vein celestite can, in principle, originate from seawater, evaporitic sulphate or oxidized pyrite. Sulphate derived from the oxidation of diagenetic pyrite by meteoric fluids can be excluded because in that case the $\delta^{18} \mathrm{O}$ and $\delta^{34} \mathrm{~S}$ values of celestite would have to be lower than measured (Ohmoto and Goldhaber 1997; Balci et al. 2007). The remaining potential reservoirs of sulphate in the region are: (1) Jurassic seawater at the time of sedimentation, (2)
Cretaceous or Miocene seawater, or (3) evaporites of Triassic age. The $\delta^{34} \mathrm{~S}$ values of celestite are higher than those in Jurassic, Cretaceous, and Tertiary seawaters (Claypool et al. 1980) and only fit with values published for the evaporites of the Upper Buntsandstein (Balderer et al. 1991). However, the $\delta^{18} \mathrm{O}$ range for this period would only partially encompass the range obtained for vein celestite (Fig. 8). More likely, a progressive bacterial reduction of aqueous sulphate (originating from Miocene or possibly Mesozoic seawater) that enriches the remaining sulphate in $\delta^{34} \mathrm{~S}$ and $\delta^{18} \mathrm{O}$ could explain the $\delta^{34} \mathrm{~S}$ and $\delta^{18} \mathrm{O}$ values of celestite (Fig. 8; Fritz et al. 1989). In support to this, the strongly negative $\delta^{34} \mathrm{~S}$ values obtained on vein pyrite suggest that bacterial reduction of marine sulphate occurred in the veins (e.g., Ohmoto and Goldhaber 1997).

The trend towards very high ${ }^{87} \mathrm{Sr} /{ }^{86} \mathrm{Sr}$ ratios of wholerock carbonate and of vein minerals in the upper part of the profile (upper Effingen Member, Geissberg Member and Crenularis Formation) is incompatible with published data for the Sr isotopic composition of Oxfordian or any other Jurassic or Cretaceous seawater (Figs. 9, 14; Veizer et al. 1999; McArthur et al. 2001). Because an internal source for the radiogenic $\mathrm{Sr}$ from clays is unlikely, the obtained ${ }^{87} \mathrm{Sr} /{ }^{86} \mathrm{Sr}$ values require a $\mathrm{Sr}$ source outside the Malm sequence. Burdigalian seawater that was present during the last marine stage in the region (deposition of the Upper Marine Molasse, 21-17 Ma) appears to be the obvious source. As Fig. 14 shows, the marine ${ }^{87} \mathrm{Sr} /{ }^{86} \mathrm{Sr}$ at that time reached up to 0.7087 . In contrast, freshwater would be unable to transport significant amounts of $\mathrm{Sr}$ and its interaction with rocks should therefore have no effect on their ${ }^{87} \mathrm{Sr} /{ }^{86} \mathrm{Sr}$ ratio. Downward transport of Burdigalian seawater through pore spaces or fractures into the 


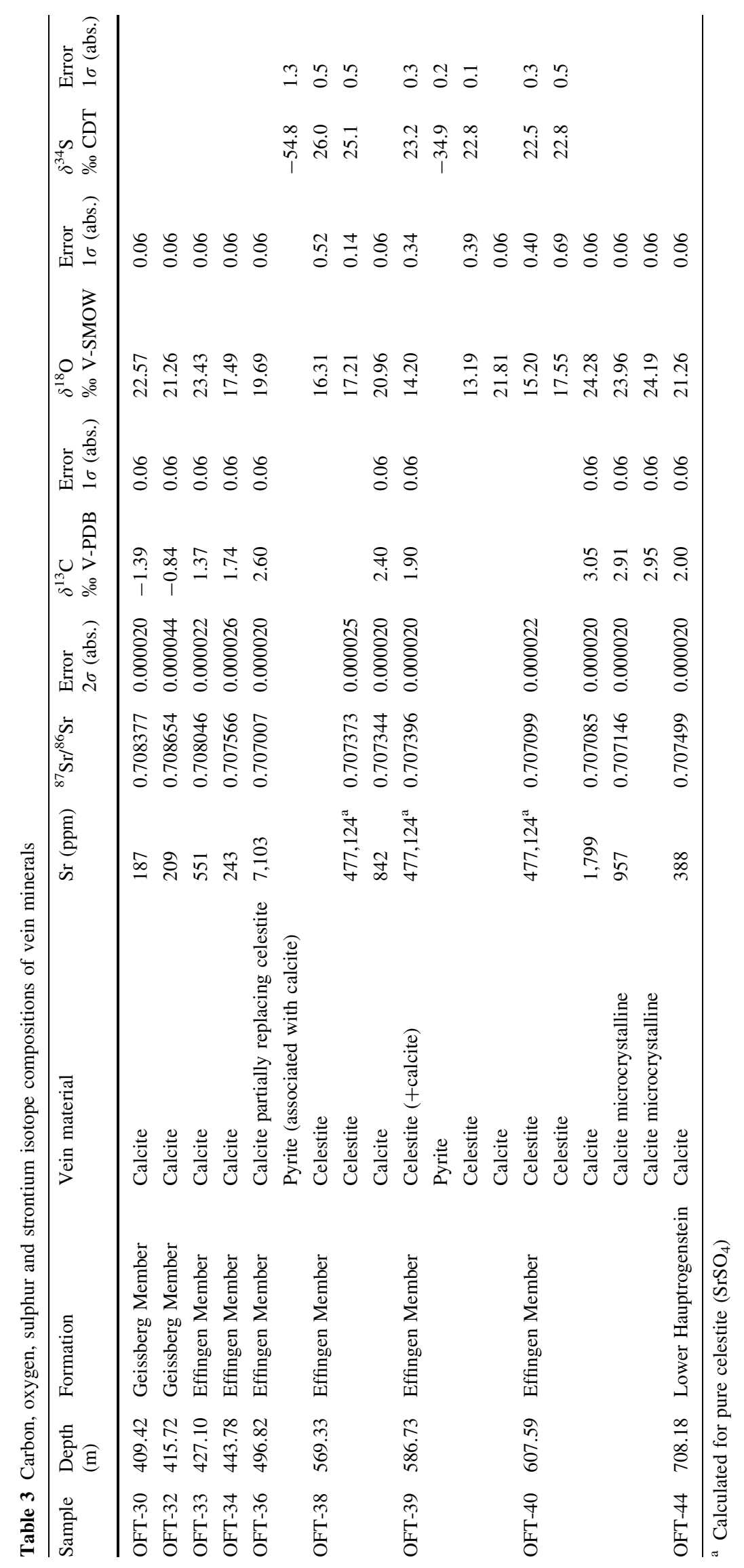




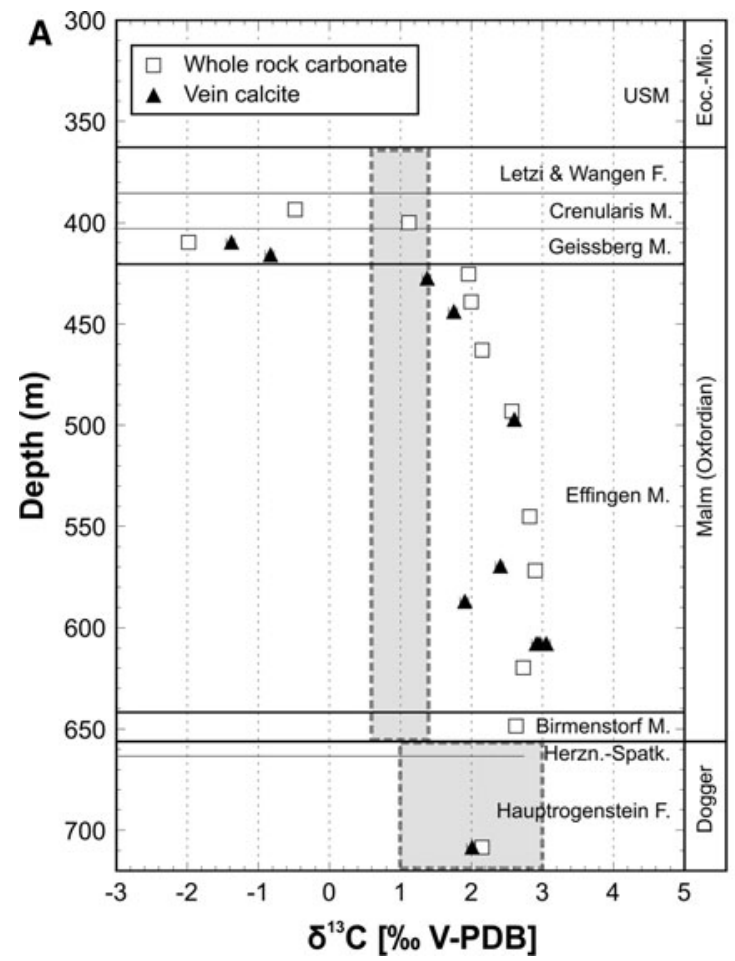

Fig. 7 Carbon and oxygen isotope composition of whole rock carbonate and of vein calcite versus depth along borehole. Ranges

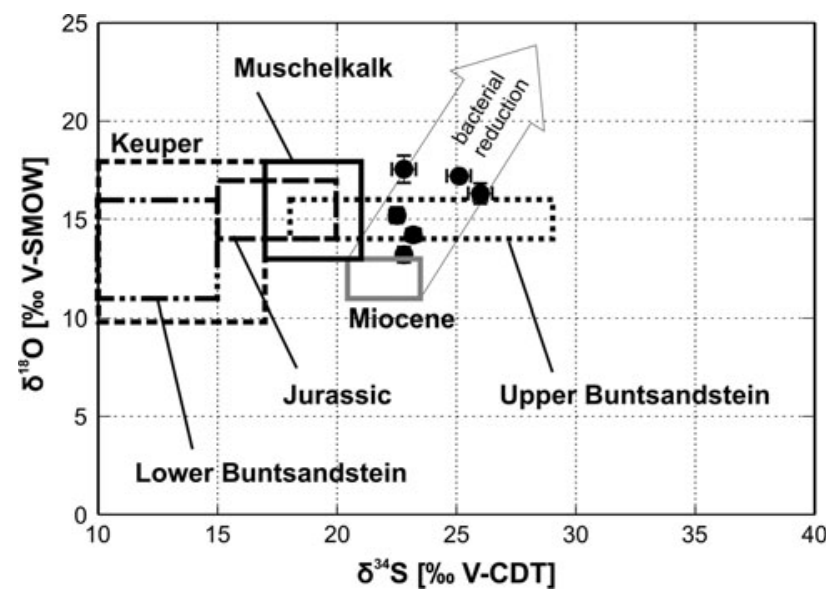

Fig. $8 \delta^{18} \mathrm{O}$ versus $\delta^{34} \mathrm{~S}$ of sulphate in celestite in comparison with the isotope composition of sulphate in evaporites of different ages in northern Switzerland and Germany as compiled by Balderer et al. (1991). Unless visible, error bars $(1 \sigma)$ are less than the symbol size

Oxfordian units and mixing with the pore water may explain the observed regular trend of the ${ }^{87} \mathrm{Sr} /{ }^{86} \mathrm{Sr}$ ratios in the host-rock carbonate and in vein minerals, decreasing with depth. Not only the vein minerals precipitated from this fluid, but also the carbonates of the rock matrix were affected by (a) recrystallization, (b) mineralogical transformation (e.g. aragonite to calcite) through dissolutionprecipitation mechanisms, and/or (c) cementation of pore and fracture space by new carbonate minerals (Banner

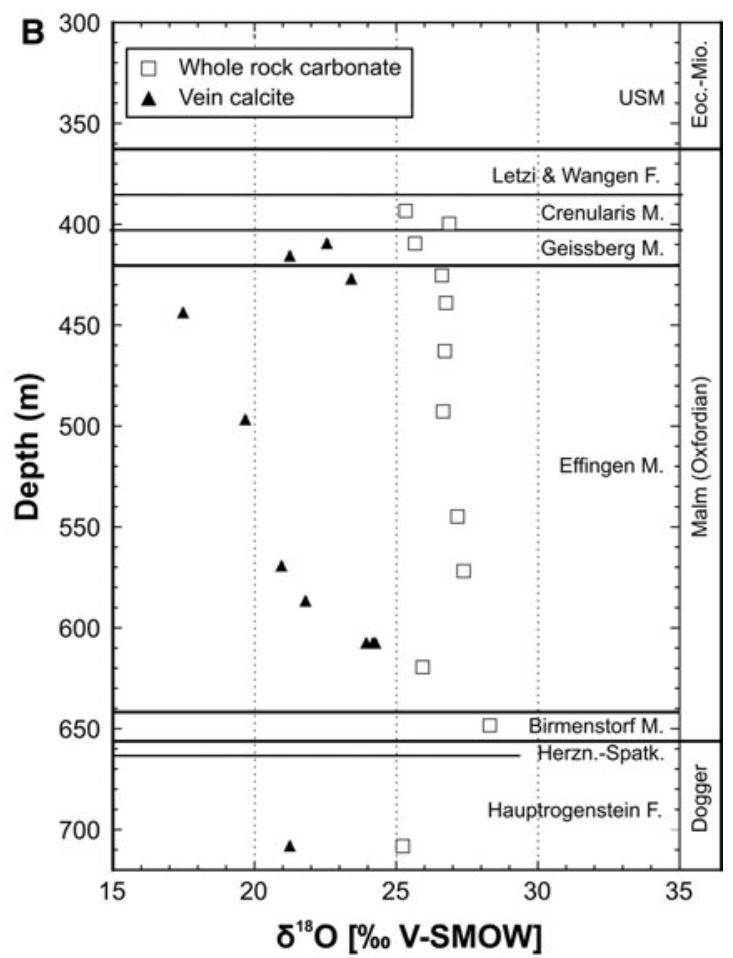

of $\delta^{13} \mathrm{C}$ values for seawater carbonate during Dogger and Oxfordian times are shown as grey boxes (after Ripperdan 2001). Errors $(1 \sigma)$ are smaller than the symbol size

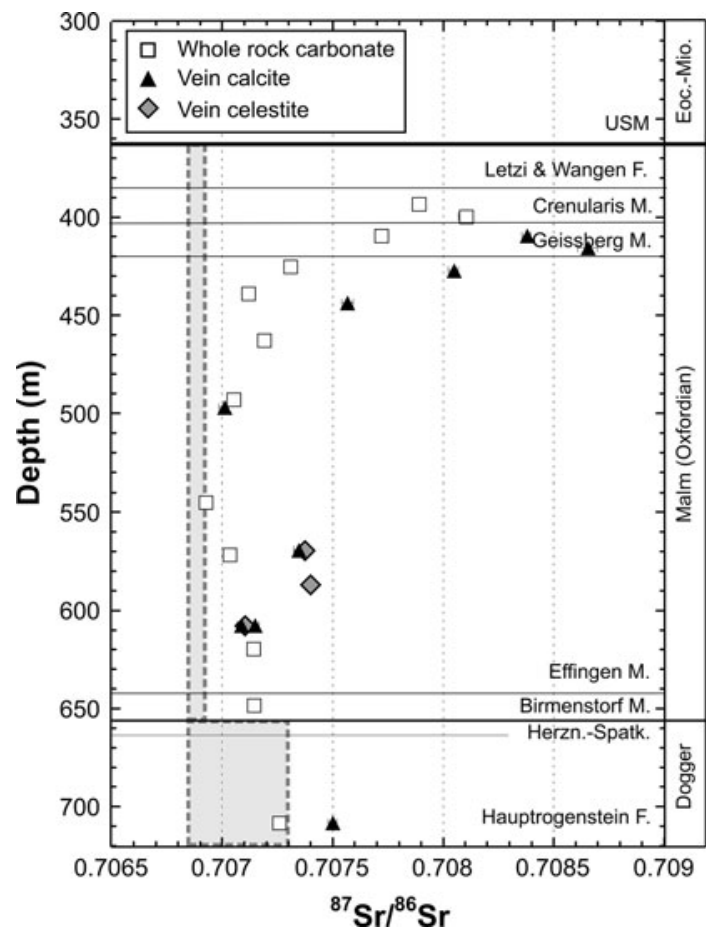

Fig. $9{ }^{87} \mathrm{Sr} /{ }^{86} \mathrm{Sr}$ of whole rock carbonate, vein calcite and vein celestite versus depth along borehole. The range of ${ }^{87} \mathrm{Sr} /{ }^{86} \mathrm{Sr}$ in seawater at the time of deposition of each lithostratigraphic unit is shown as grey boxes (McArthur et al. 2001). Unless visible, error bars $(2 \sigma)$ are smaller than the symbol size 


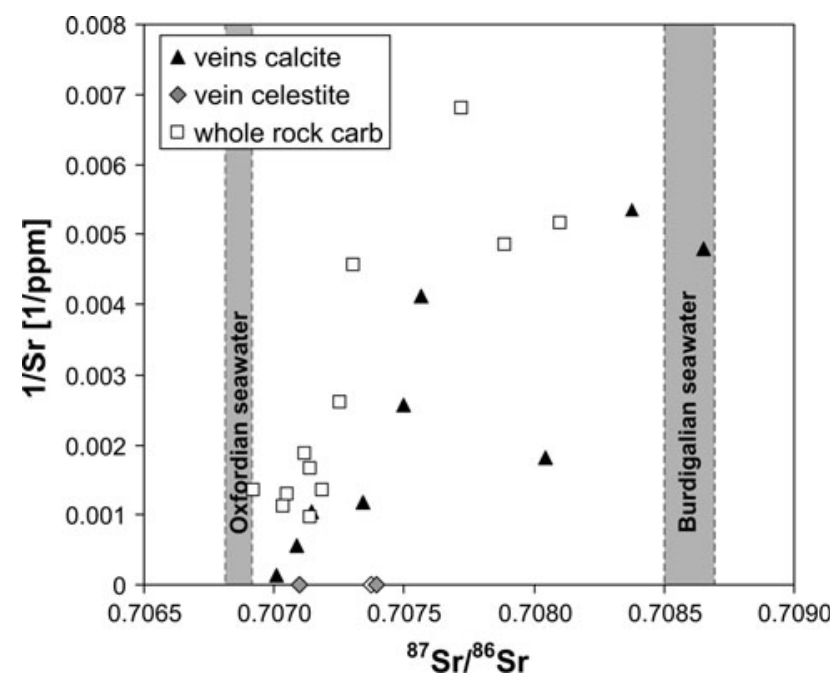

Fig. $101 / \mathrm{Sr}$ content versus ${ }^{87} \mathrm{Sr} /{ }^{86} \mathrm{Sr}$ ratio of vein minerals and whole-rock carbonate. Grey boxes correspond to the ${ }^{87} \mathrm{Sr} /{ }^{86} \mathrm{Sr}$ ratio for Oxfordian (Jurassic) and Burdigalian (Miocene) seawater following McArthur et al. (2001)

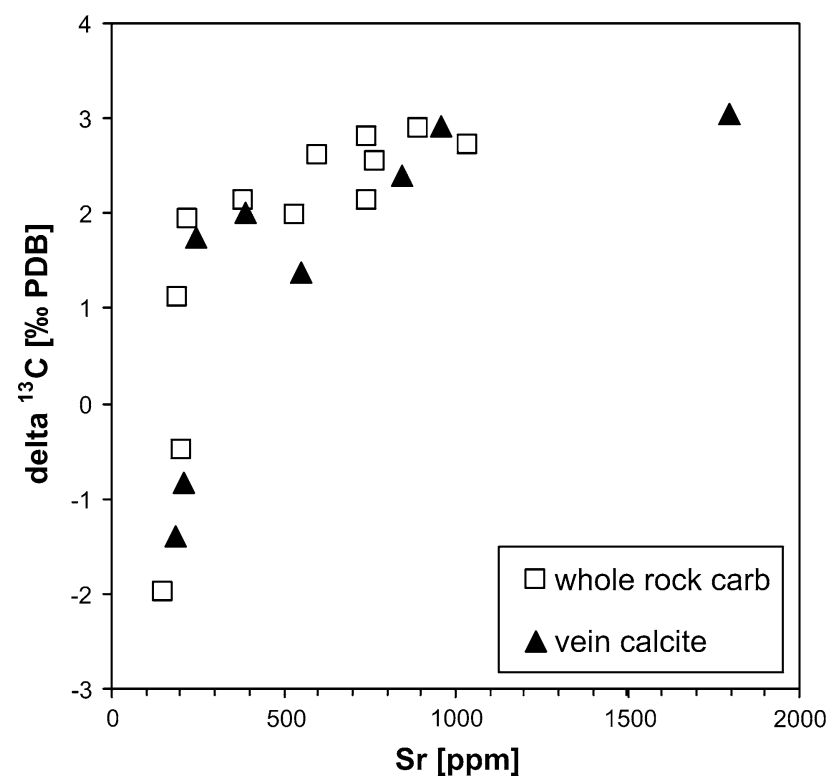

Fig. $11 \delta^{13} \mathrm{C}$ versus $\mathrm{Sr}$ content of whole-rock carbonate and vein calcite

1995). The likely precipitation mechanisms for vein minerals are heating of the descending seawater along the geothermal gradient (e.g., Rimstidt 1997) and mixing with local pore waters. Precipitation of vein pyrite resulted from the bacterial reduction of part of the seawater sulphate.

The involvement of Burdigalian seawater, descending along fractures and mixing with the local $\mathrm{Sr}$ signatures, is in agreement with the $\mathrm{S}$ and $\mathrm{O}$ isotopic data obtained on vein celestite, and with the range of obtained salinities (1.4-5.3 wt $\% \mathrm{NaCl}$ eq.), broader than the average $3-4 \mathrm{wt} \% \mathrm{NaCl}$ eq. observed in modern seawater, but compatible with the

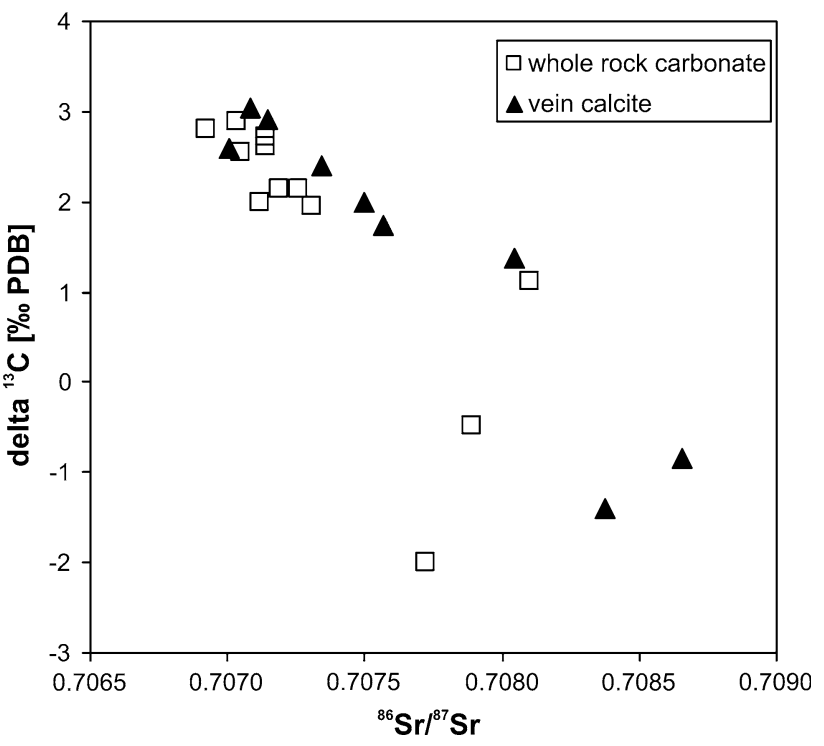

Fig. $12 \delta^{13} \mathrm{C}$ versus ${ }^{86} \mathrm{Sr} /{ }^{87} \mathrm{Sr}$ ratio of whole-rock carbonate and vein calcite

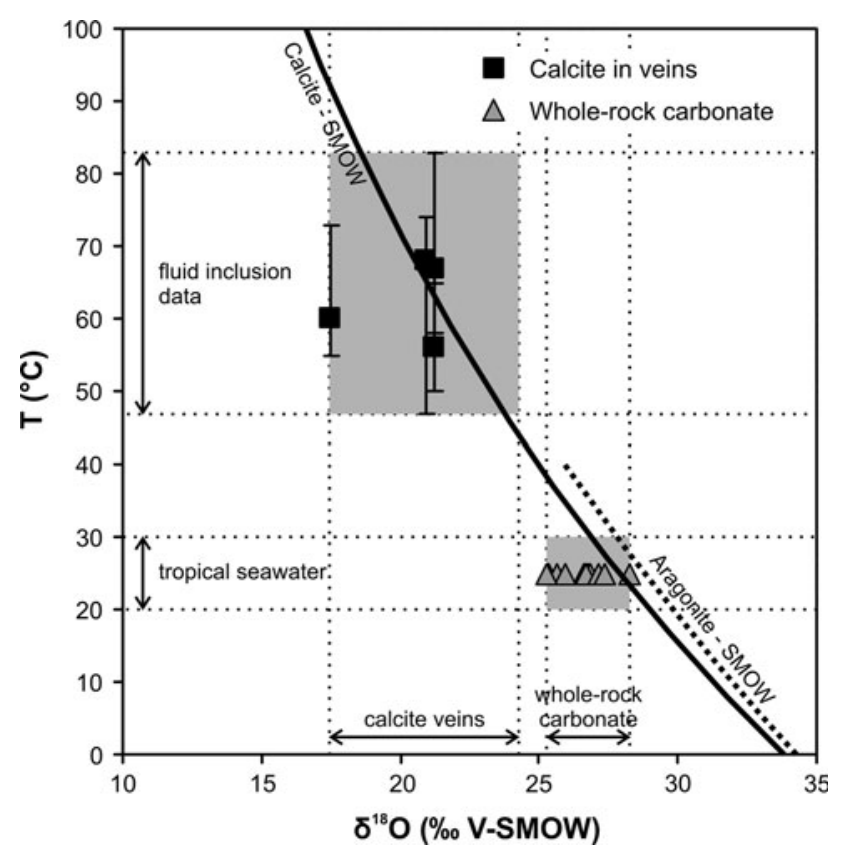

Fig. $13 \delta^{18} \mathrm{O}$ values of calcite (O’Neil et al. 1969) and aragonite (Kim et al. 2007) in equilibrium with seawater (SMOW) as a function of precipitation temperature, compared with actually measured values (temperature data are from fluid inclusion measurements, see Table 1). Whole rock carbonate data are plotted at $25^{\circ} \mathrm{C}$, the average temperature for tropical seawater

salinity range of an episodically brackish sea (Kuhlemann and Kempf 2002). In contrast, the data cannot be explained by contributions from the underlying Triassic evaporites. The negative $\delta^{13} \mathrm{C}$ signature $(\leq-2 \%$ V-PDB) of the descending fluid can be explained by the bacterial seawater sulphate reduction on the way down, which would have produced $\mathrm{CO}_{2}$ with negative $\delta^{13} \mathrm{C}$ value from organic matter. 


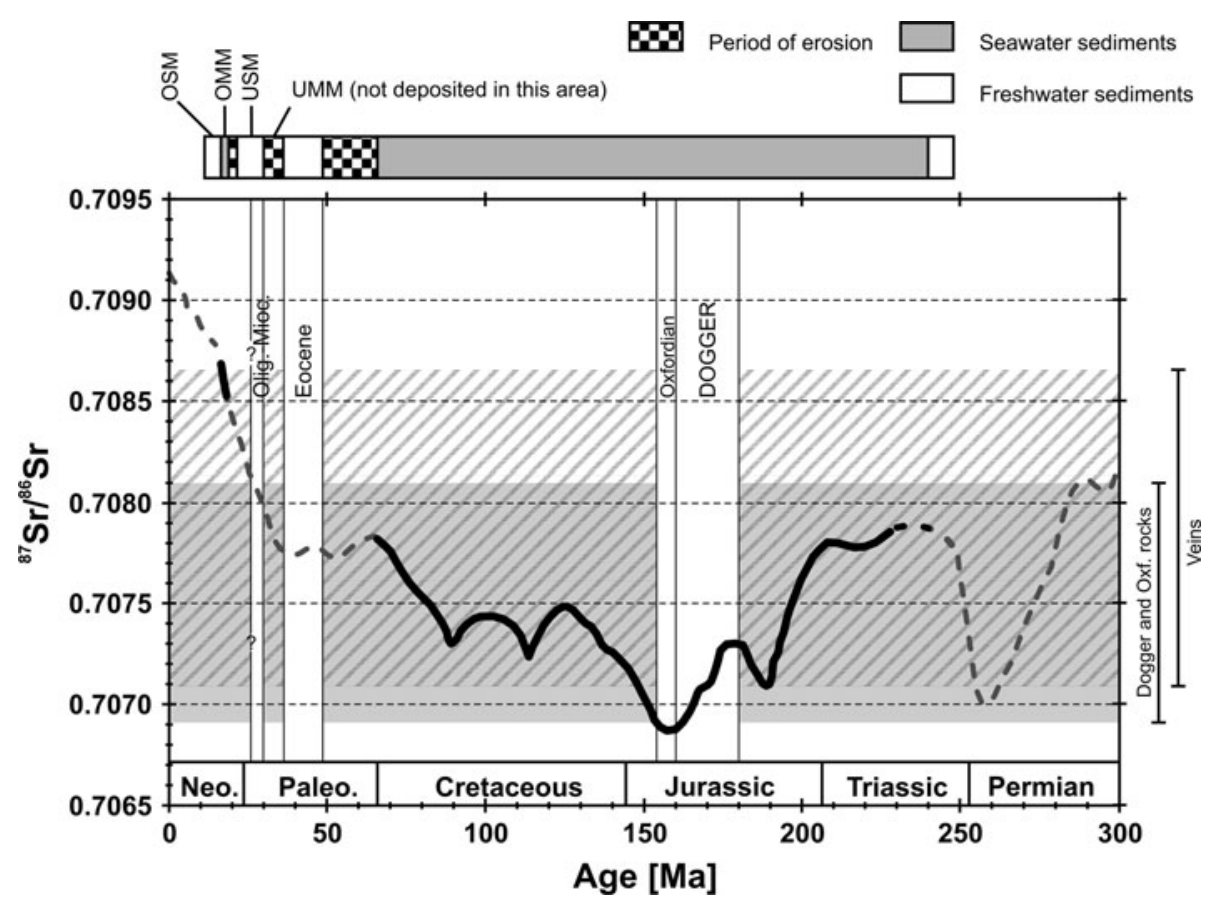

Fig. 14 Permian to present $\mathrm{Sr}$ isotope composition of seawater (from McArthur et al. 2001) in comparison to the $\mathrm{Sr}$ isotope composition of rocks and minerals from the Oftringen core. Times of marine and freshwater sedimentation and erosion in the studied area (top of figure) are from Kuhlemann and Kempf (2002). The curve of the ${ }^{87} \mathrm{Sr} /{ }^{86} \mathrm{Sr}$ ratio of seawater over time is solid black when marine conditions prevailed in the region of interest and dotted grey for continental conditions. The grey area indicates the ${ }^{87} \mathrm{Sr} /{ }^{86} \mathrm{Sr}$ range of whole-rock carbonate, and the hatched area represents the range for calcite and celestite from veins. White areas show the preserved sedimentary sequence as encountered in the borehole. The upper limit of the Oligocene-Miocene field has a question mark because the exact timing of the erosive surface in the Lower Freshwater Molasse is unknown. Time of deposition of each molasse unit is shown on top of the figure: $O S M$ Upper Freshwater Molasse, OMM Upper Marine Molasse, USM Lower Freshwater Molasse, UMM Lower Marine Molasse

finally led to the downward migration of Molasse water into the underlying Jurassic units. The fact that the salinity of fluid inclusions in vein minerals varies substantially indicates that fluid infiltration was not a single event but more likely a complex process.

In spite of the currently low vertical hydraulic conductivities of the Lower Freshwater Molasse (1E-12 to $1 \mathrm{E}-11 \mathrm{~m} / \mathrm{s}$, Prestel 1990; Fig. 2), the values may have been higher in the past, at least episodically. This is corroborated by the fact that oil of Mesozoic provenience has been found in the Lower Freshwater Molasse of the Oftringen borehole (Waber 2008). The ascent of this oil must have taken place through feeder fractures after the deposition of this unit, i.e. in the Burdigalian or later.

\section{Conclusions}

The upper Dogger and lower Malm units of the Oftringen borehole contain veins filled by hydrothermal calcite with or without celestite and minor pyrite that precipitated at average temperatures of $56-68^{\circ} \mathrm{C}$ from moderately saline 
fluids. Isotope data $(\mathrm{O}, \mathrm{C}, \mathrm{S}$, and $\mathrm{Sr})$ suggest that the mineralising fluid was descending Burdigalian (Miocene) seawater from the time of Upper Marine Molasse (OMM) deposition. This seawater reacted with the host sequence on its way down and sulphate and carbonate vein minerals probably precipitated in response to heating along the geothermal gradient and to mixing with local pore water. Involvement of a deeply sourced, ascending fluid enriched in Triassic sulphate and $\mathrm{Sr}$ would not explain the shape of the $\mathrm{Sr}$ isotope profile. There are no direct constraints on the timing of this process. Given the elevated temperatures obtained from fluid-inclusion studies, it must have taken place at depths corresponding to maximum burial in the late Miocene and was possibly linked to the thrusting of the Folded Jura belt.

Acknowledgments We thank Nagra (Wettingen, Switzerland) for financial support of the study, and Dr. Rossana Martini for her help for the optical cathodoluminescence at the University of Geneva. Comments provided by O. Kempf (swisstopo) and an anonymous reviewer are warmly acknowledged.

\section{References}

Albert, W., \& Bläsi, H. R. (2008). NOK EW-Bohrung Oftringen: Geologische, mineralogische und bohrlochgeophysikalische Untersuchungen (Rohdatenbericht). Nagra report, Nagra. Switzerland: Wettingen.

Balci, N., Shank, W. C., I. I. I., Mayer, B., \& Mandernack, K. W. (2007). Oxygen and sulphur isotope systematics of sulphate produced by bacterial and abiotic oxidation of pyrite. Geochimica et Cosmochimica Acta, 71, 3796-3811.

Balderer, W., Pearson, F. J., \& Soreau, S. (1991). Sulphur and oxygen isotopes in sulphate and sulphide. In F. J. Pearson Jr, W. Balderer, H. H. Loosli, B. E. Lehmann, A. Matter, T. Peters, H. Schmassmann, \& A. Gautschi (Eds.), Applied isotope hydrogeology-A case study in northern Switzerland. Studies in Environmental Sciences 43 (pp. 297-322). Amsterdam: Elsevier.

Banner, J. L. (1995). Application of the isotope and trace element geochemistry of strontium to studies of diagenesis in carbonate systems. Sedimentology, 42, 805-824.

Becker, A. (2000). The Jura Mountains-An active foreland fold-andthrust belt? Tectonophysics, 321, 381-406.

Berger, J. P. (1996). Cartes paléogéographiques-palinspastiques du bassin molassique suisse (Oligocène inférieur-Miocène moyen). Neues Jahrbuch für Geologie Paläontologie, 202, 1-44.

Bodnar, R. J. (1993). Revised equation and table for determining the freezing point depression of $\mathrm{H}_{2} \mathrm{O}-\mathrm{NaCl}$ solutions. Geochimica et Cosmochimica Acta, 57, 683-684.

Claypool, G. E., Holser, W. T., Kaplan, I. R., Sakai, H., \& Zak, I. (1980). The age curves of sulphur and oxygen isotopes in marine sulphate and their mutual interpretation. Chemical Geology, 28, 199-260.

Dold, B., \& Spangenberg, J. E. (2005). Sulfur speciation and stable isotope trends of water-soluble sulfates in mine tailings profiles. Environmental Science and Technology, 39, 5650-5656.

Friedman, I., O’Neil, J., \& Cebula, G. (1982). Two new carbonate stable isotope standards. Geostandards Newsletter, 6, 11-12.

Fritz, P., Basharmal, G. M., Drimmie, R. J., Ibsen, J., \& Qureshi, R. M. (1989). Oxygen isotope exchange between sulphate and water during bacterial reduction of sulphate. Chemical Geology, 79, 99-105.

Füchtbauer, H. (1988). Sedimente und Sedimentgesteine (p. 1141). Stuttgart: Schweizerbart Verlagsbuchhandlung.

Giesemann, A., Jager, H. J., Norman, A. L., Krouse, H. P., \& Brand, W. A. (1994). Online sulfur-isotope determination using an elemental analyzer coupled to a mass-spectrometer. Analytical Chemistry, 66, 2816-2819.

Holser, W. T., Magaritz, M., \& Ripperdan, R. L. (1995). Global isotopic events. In O. H. Walliser (Ed.), Global events and event stratigraphy in the phanerozoic (pp. 63-88). Berlin: Springer.

Kim, S. T., O’Neil, J. R., Hillaire-Marcel, C., \& Mucci, A. (2007). Oxygen isotope fractionation between synthetic aragonite and water: influence of temperature and $\mathrm{Mg}^{2+}$ concentration. Geochimica et Cosmochimica Acta, 71, 4704-4715.

Kuhlemann, J., \& Kempf, O. (2002). Post-Eocene evolution of the North Alpine Foreland Basin and its response to Alpine tectonics. Sedimentary Geology, 152, 45-78.

Marquer, D., \& Burkhard, M. (1992). Fluid circulation, progressive deformation and mass-transfer processes in the upper crust: the example of basement-cover relationships in the External Crystalline Massifs, Switzerland. Journal of Structural Geology, 14, 1047-1057.

Mazurek, M., Hurford, A. J., \& Leu, W. (2006). Unravelling the multi-stage burial history of the Swiss Molasse Basin: Integration of apatite fission track, vitrinite reflectance and biomarker isomerisation analysis. Basin Research, 18, 27-50.

McArthur, J. M., Howarth, R. J., \& Bailey, T. R. (2001). Strontium isotope stratigraphy: LOWESS Version 3: Best fit to the marine Sr-isotope curve 0-509 Ma and accompanying look-up table for deriving numerical age. Journal of Geology, 109, 155-170.

Meisser, N. (1997). La célestine de Baulmes (Jura vaudois). Le Cristallier Suisse, 11, 1-5.

Moore, L. J., Murphy, T. J., Barnes, I. L., \& Paulsen, P. J. (1982). Absolute isotopic abundance ratios and atomic weight of a reference sample of strontium. Journal of Research of the National Institute of Standards and Technology, 87, 1-8.

Ohmoto, H., \& Goldhaber, M. B. (1997). Sulfur and carbon isotopes. In H. L. Barnes (Ed.), Geochemistry of hydrothermal ore deposits (3rd ed., pp. 517-611). New York: Wiley.

O’Neil, J. R., Clayton, R. N., \& Mayeda, T. K. (1969). Oxygen isotope fractionation in divalent metal carbonates. Journal of Chemistry and Physics, 51, 5547-5558.

Pearson, F.J., Arcos D., Bath, A., Boisson, J.Y., Fernandez, A.M., Gaebler, H.E., Gaucher, E.C., Gautschi, A., Griffault, L., Hernan, P., \& Waber, H.N. (2003). Mont Terri ProjectGeochemistry of water in the Opalinus clay formation at the Mont Terri Rock Laboratory. In Reports of the Federal Office of Water and Geology (FOWG), Geology Series No. 5.

Prestel, R. (1990). Untersuchungen zur Diagenese von MalmKarbonatgesteinen und Entwicklung des Malm-Grundwassers im süddeutschen Molassebecken. Unpublished $\mathrm{PhD}$ thesis, University of Stuttgart, Deutschland.

Rimstidt, J.D. (1997). Gangue mineral transport and deposition. In H.L. Barnes, (Ed.), Geochemistry of hydrothermal ore deposits (3rd ed., pp. 487-515), New York: Wiley.

Ripperdan, R. L. (2001). Stratigraphic variation in marine carbonate carbon isotope ratios. Reviews in Mineralogy and Geochemistry, $43,637-662$.

Roedder, E. (1984). Fluid inclusions. Mineralogical Society of America, Reviews in Mineralogy (Vol. 12).

Romanek, C. S., Grossman, E. L., \& Morse, J. W. (1992). Carbon isotopic fractionation in synthetic aragonite and calcite: effects of temperature and precipitation rate. Geochimica et Cosmochimica Acta, 56, 419-430. 
Schlunegger, F., \& Mosar, J. (2010). The last erosional stage of the Molasse Basin and the Alps. International Journal of Earth Sciences. doi:10.1007/s00531-010-0607-1.

Stalder, H. A., Wagner, A., Graeser, S., \& Stuker, P. (1998). Mineralienlexikon der Schweiz. Basel, Switzerland: Verlag Wepf \& Co. AG.

Veizer, J., Ala, D., Azmy, K., Bruckschen, P., Buhl, D., Bruhn, F., et al. (1999). ${ }^{87} \mathrm{Sr} /{ }^{86} \mathrm{Sr}, \delta^{13} \mathrm{C}$ and $\delta^{18} \mathrm{O}$ evolution of Phanerozoic seawater. Chemical Geology, 161, 59-88.

Waber, H. N. (Ed.). (2008). Borehole Oftringen: Mineralogy, porosimetry, geochemistry, pore water chemistry. Nagra, Wettingen, Switzerland: Nagra report.
Waber, H. N., \& Schürch, R. (2000). WS-A experiment: Fracture mineralogy and geochemistry as constraints on porewater composition. St Ursanne, Switzerland: Mont Terri Consortium Report.

Weibel, M. (1966). A guide to the minerals of Switzerland (p. 123). London: Wiley.

Weissert, H., \& Erba, E. (2004). Volcanism, $\mathrm{CO}_{2}$ and palaeoclimate: A late jurassic-early cretaceous carbon and oxygen isotope record. Journal of the Geological Society, London, 161, 1-8.

Willett, S. D., \& Schlunegger, F. (2010). The last phase of deposition in the Swiss Molasse Basin: From foredeep to negative-alpha basin. Basin Research, 22, 623-639. 